\title{
Estimation on Residual Stress in Porcelain/Alloy System by Thermal Shock Test
}

\author{
Kenzo ASAOKA and Norihiko KUWAYAMA \\ Department of Dental Engineering, School of Dentistry, Tokushima University, 3-18-15 Kuramoto-cho, \\ Tokushima 770, Japan
}

Received on April 4, 1986

Accepted on November 5, 1986

Computer calculations were used to simulate the effects of thermal shock on the stresses developed in porcelain-fused-to-metal (PFM) systems. A three-dimensional-finite-element model was employed to first calculate time-dependent temperature distribution in a beam shaped specimen $1.25-2.5 \times 8 \times 20 \mathrm{~mm}$. These were then used in a two-dimensional analysis of stresses in a beam consisting of 50 elements. Transient stresses in a beam consisting of 50 elements were calculated for porcelain, porcelain with an opaque layer, and porcelain-opaque-alloy system; the effects of porcelain thickness, thermal expansion coefficients, and quenching temperatures were evaluated. Experimental tests were also conducted for correlation with the theoretical calculations.

Results show that for $\alpha_{m}$ (metal) $>\alpha_{p}$ (porcelain), the highest stresses occur on the surface, and the interface stress is lower than $\alpha_{m}=\alpha_{p}$. When $\alpha_{m}<\alpha_{p}$, the surface stress is lower, and the interface stress is higher than $\alpha_{m}=\alpha_{p}$. When $\alpha_{p}-\alpha_{m}<2 \times 10^{-6 \circ} \mathrm{C}^{-1}$, cracks are more easily initiated in the porcelain surface rather than the interface. Theory and experiment are in general agreement.

Key words: Porcelain-fused-to-metal, Thermal Shock Test, Residual Stress

\section{INTRODUCTION}

The study of porcelain-fused-to-metal (PFM) restorations has included interest in the bond strength. Bending, pull-out, and push-out tests were adapted for this purpose. Anusavice $e t$ al. ${ }^{1)}$ discussed eleven PFM bond tests and Asaoka and Kuwayama ${ }^{2)}$ computed interfacial shear stress distribution for pull-out tests using finite-element stress analysis. Dehoff et $a l .^{3)}$ compared the experimental observation of fracture from the finite-element stress analysis of a four-point flexural test for PFM. These studies show that the actual bond strength is very difficult to measure because the stress distribution along the interface is not uniform in every test specimen. Thus, recent research emphasis has shifted from measuring PFM bond strength to compatibility of PFM. Asaoka and Kuwayama ${ }^{4,5)}$ calculated the thermal residual stress in a PFM composite beam after firing using beam theory. Tesk et al. ${ }^{6,7)}$ conducted the effect of thermal expansion coefficient $(\alpha)$ and thickness ratio variations on gap displacement for a three-layered split ring. Dehoff and Anusavice ${ }^{8)}$ calculated residual stresses due to thermal contraction differences in PFM using semicircular arch. Walton and O'Brien" ${ }^{9}$ examined crack development due to thermal stress in porcelain, which had different values of thermal expansion coefficient, bonded to palladium-silver alloy. Anusavice et al. 10-12) employed a thermal shock test for disc shaped specimens to help determine the compatibility of PFM.

The objective of this study was to employ non-steady-state heat-transfer analysis and two dimensional composite beam stress analysis to calculate the effect of residual stress in 
a PFM beam on the thermal shock resistance.

\section{MATERIALS AND METHODS}

Simulation Method--Time-dependent temperature distributions in a beam shaped porcelain 1.25 and $2.5 \times 8 \times 20 \mathrm{~mm}$, were simulated using a non-steady-state heat-transfer finite element method. The transient stresses in the beam arise from the differences in the local thermal contraction in the beam. These stresses can be calculated from the thermal contraction and the temperature distributions at any given time.

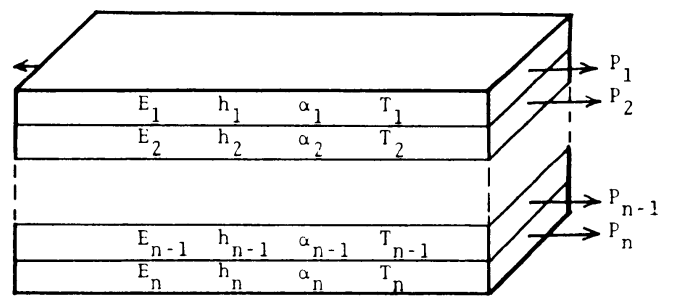

Fig. 1 Segment of an $n$-layer strip. $E_{1}, E_{2}, E_{n-1}$ and $E_{n}$ are elastic moduli ; $h_{i}, h_{2}$, $h_{n-1}$ and $h_{n}$, thicknesses of layer; $\alpha_{1}, \alpha_{2}, \alpha_{n-1}$ and $\alpha_{n}$, linear coefficients of thermal expansion; and $T_{1}, T_{2}, T_{n-1}$ and $T_{n}$ temperatures.

In this study, the specimen is divided into $\mathrm{n}$ thin layers as shown in Fig. 1. There are no external forces acting on the specimen. That is,

$$
\sum_{i=1}^{\mathrm{n}} P_{i}=0
$$

where $P_{i}$ is the axial load of the ith material. Then the relation between the moments of each element is given by :

$$
\sum_{i=1}^{\mathrm{n}} k_{i} P_{i}=\sum_{\mathrm{i}=1}^{\mathrm{n}} E_{i} I_{i} / \rho \quad \text { here, } k_{i}=\frac{h_{o}-h_{i}}{2}-\sum_{\mathrm{j}=1}^{\mathrm{i}-1} h_{j}
$$

where $E_{i}$ is the modulus of elasticity of the ith material ; $I_{i}$, the moment of inertia of area ; $h_{i}$, the thickness of the ith material; and $h_{o}$ is the total thickness of the beam.

$$
I_{i}=\frac{b h_{i}^{3}}{12}
$$

where $b$ is the strip width.

The next $(n-1)$ equations must be evaluated because all of the elements bond to each other.

$$
\alpha_{k} T_{k}+P_{k} /\left(E_{k} b h_{k}\right)+h_{k} / 2 \rho=\alpha_{k+1} T_{k+1}+P_{k+1} /\left(E_{k+1} b h_{k+1}\right)-h_{k+1} / 2 \rho
$$

where $\alpha_{k}$ and $\alpha_{k+1}$ are respectively the coefficients of thermal expansion of ith and $(i+1) t h$ materials; $T_{k}$ and $T_{k+1}$, the temperatures; and $\rho$ is the radius of curvature of the beam. From these $(n+1)$ equations, $P_{1}-P_{n}$ and $1 / \rho$ can be calculate. Thus, the normal stresses $\left(\sigma_{k 1}\right.$ and $\left.\sigma_{k 2}\right)$ at the interface in material $k$ can be calculated from $P_{k}$ and $1 / \rho$. 


$$
\begin{aligned}
& \sigma_{k 1}=-E_{k} h_{k} / 2 \rho+P_{k} / h_{k} b \\
& \sigma_{k 2}=E_{k} h_{k} / 2 \rho+P_{k} / h_{k} b
\end{aligned}
$$

If metal and porcelain have the same thermal expansion coefficient, internal normal stress does not develop from an equilibrium temperature change. Dynamic temperature change causes normal transient stress in the material. When the alloy has a different coefficient of thermal expansion from the porcelain, the normal internal stress is given by the sum of the equilibrium internal stress and the dynamic normal stress. The physicomechanical properties of the porcelain in this study and the conditions are shown in Table 1.

\begin{tabular}{cc} 
Table 1 Physical and mechanical properties of porcelain and calculation conditions \\
\hline Thermal conductivity & $0.0025 \mathrm{cal} / \mathrm{cm} \mathrm{s}^{\circ} \mathrm{C}$ \\
Density & $2.5 \mathrm{~g} / \mathrm{cm}^{3}$ \\
Specific heat & $0.20 \mathrm{cal} / \mathrm{g}^{\circ} \mathrm{C}$ \\
Coefficient of thermal expansion & $14 \times 10^{-6} /{ }^{\circ} \mathrm{C}$ \\
Modulus of elasticity & $70 \mathrm{GPa}$ \\
Time step increments & $0.01 \mathrm{~s}$ \\
Number of time steps & $500 \mathrm{steps}$ \\
\hline
\end{tabular}

Experimental method-Ceramco ${ }^{1}$ Gingival Al porcelain, Paint-O-Pake Al porcelain and three kinds of casting alloys ${ }^{2}$ were used in this investigation. Specimens were made as follows: Porcelain powder was first weighed and placed in $10 \times 30 \mathrm{~mm}$ stainless dies. The powder was preformed into useful shapes by a 4 ton $\left(1.3 \mathrm{ton} / \mathrm{cm}^{2}\right)$ force. The shaped powder was preheated to $650^{\circ} \mathrm{C}$ for five minutes on a stainless steel plate and made into a biscuit. The biscuit was baked on the porcelain investment up to $650^{\circ} \mathrm{C}$ in air, $650-930^{\circ} \mathrm{C}$ in vacuum and up to $1000^{\circ} \mathrm{C}$ in air. The specimen was then slowly cooled in the furnace. The quenching test specimen was modified to the shape to be used. Each specimen was then heated up to $800^{\circ} \mathrm{C}$ in air for 10 minutes in the furnace and slowly cooled in the furnace before the quenching test. The thermal shock test was then conducted. The specimen was held in the furnace at the quenching temperature for 20 minutes and then quenched into ice water. The cracks in the specimen were observed using an optical microscope. The magnification was about 50 and 100. If the specimen had no cracks, the quenching temperature raised $10^{\circ} \mathrm{C}$ and the same tests were continued.

\section{RESULTS AND DISCUSSION}

Porcelain-For the specimen which was held at $100^{\circ} \mathrm{C}$ and then quenched into ice water $\left(0^{\circ} \mathrm{C}\right)$, the time dependent temperature distribution in the beam with $2.5 \mathrm{~mm}$ thickness (Specimen A) is shown in Fig. 2. The specimen has a large gradient of temperature in the

${ }^{1}$ Ceramco, Inc., East Windson, NJ, USA

2 Alloy A : Ultratek; Ni 80.48-Cr 11.39-Co 0.50-Al 2.22-Be 1.60-Fe 2.00-Mo 1.99 ; Metals for Modern Dentistry, Inc., Concord, CA, USA

Alloy B : Porcelain Metal 12K ; Au 50-Pt 1-Pd 25-Ag 18-In 5-etc.; Sankin Industry Co., Ltd., Osaka, Japan

Alloy C: Porcelain Gold ; Au 83-Pt 7-Pd 7-Ag 1-Ir 1-etc. ; Sankin Industry Co., Ltd., Osaka, Japan 
initial stages from the time of bathing in ice water. The temperature is gradually changed to a flat distribution, and eventually reaches to the uniform distribution at last. Figure 3 shows how temperature changes with time. The points $\mathrm{A}, \mathrm{B}$, and $\mathrm{C}$ represent the 1.25 and $0.625 \mathrm{~mm}$ from the surface of specimen $\mathrm{A}$, and the center part of the beam with thickness 1.25 mm (Specimen B), respectively.

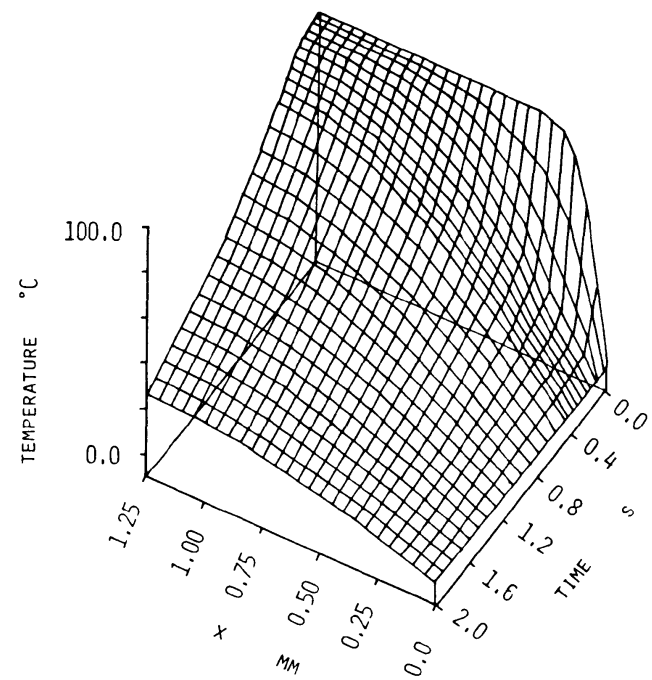

Fig. 2 Time dependent temperature distribution across the porcelain beam with 2.5 $\mathrm{mm}$ thickness quenching in $0^{\circ} \mathrm{C}$ ice water from heat-soak temperature $100^{\circ} \mathrm{C}$.

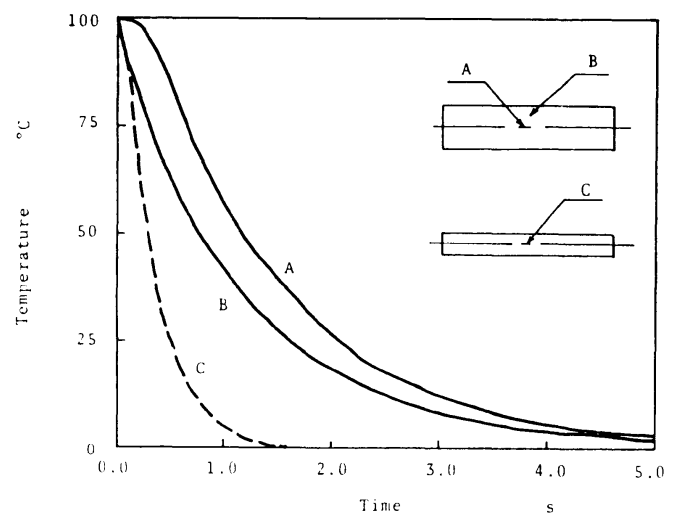

Fig. 3 Temperature-Time curves for the procelain beams with the thicknesses of 2.5 and $1.25 \mathrm{~mm}$ neat-soaked at $100^{\circ} \mathrm{C}$ and quenched in $0^{\circ} \mathrm{C}$ ice water.

Transient stresses were calculated from these temperature distributions as shown in Figs. 4 and 5. The vertical axis represents the transient stress and the horizontal axes represents time and distance from the surface of the specimen. The surface has tensile stress and the center part of the specimen has compressive stress. Maximum compressive stresses reached $26 \mathrm{MPa}$ for specimen $\mathrm{A}$, and $24 \mathrm{MPa}$ for specimen $\mathrm{B}$, respectively. Maximum tensile stresses were 65 and $55 \mathrm{MPa}$. 


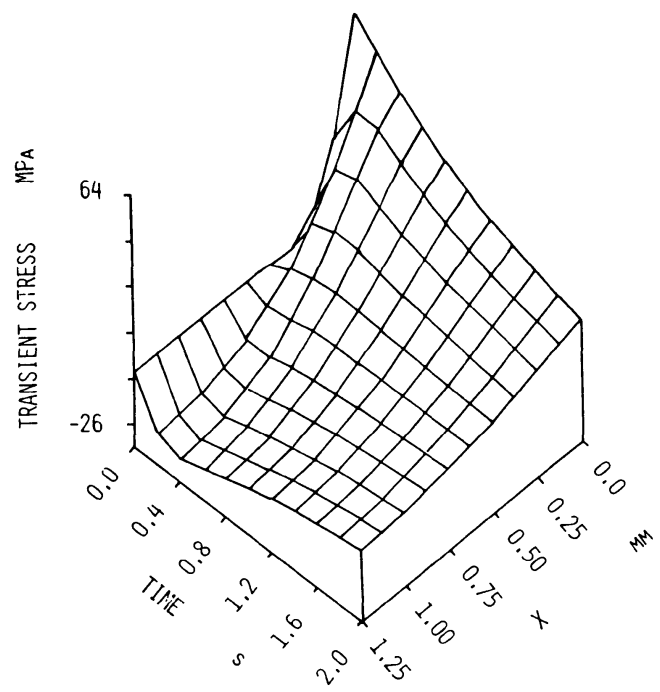

Fig. 4 Transient stress distribution profile for the porcelain beam with $2.5 \mathrm{~mm}$ thickness heat-soaked at $100^{\circ} \mathrm{C}$ and quenched in $0^{\circ} \mathrm{C}$ ice water.

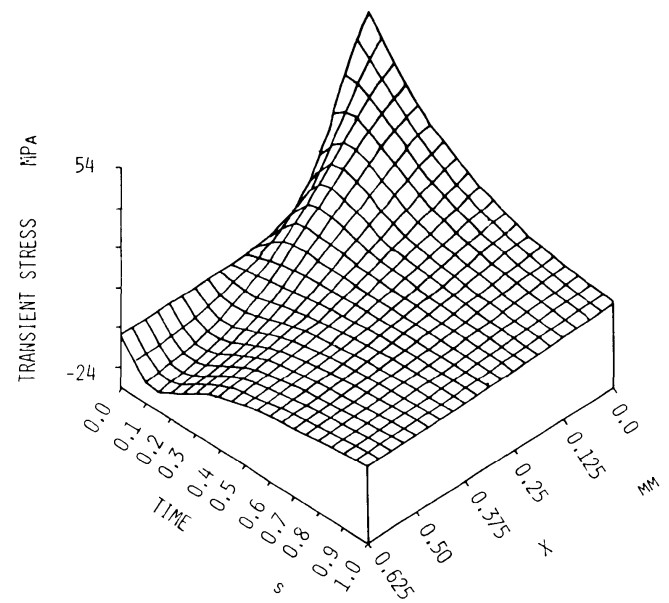

Fig. 5 Transient stress distribution profile for the porcelain beam with $1.25 \mathrm{~mm}$ thickness heat-soaked at $100^{\circ} \mathrm{C}$ and quenched in $0^{\circ} \mathrm{C}$ ice water.

Figure 6 shows the relation between the transient stress and quenching temperature. The solid lines show the maximum tensile stresses at the surface of the specimen $\mathrm{A}$ at the 0.01 , 0.5 and $1.0 \mathrm{~s}$ after quenched. This result shows clearly that the transient stress is directly proportional to the quenched temperature and confirms the work of Anusavice et al. ${ }^{21}$ The tensile strength of porcelain will then be able to be estimated from the quenched temperature of thermal shock tests provided other properties are well known.

Figure 7 shows the relation between the transient stress and the coefficient of thermal expansion of porcelain. The results, of course, show that this relation is proportional. When 


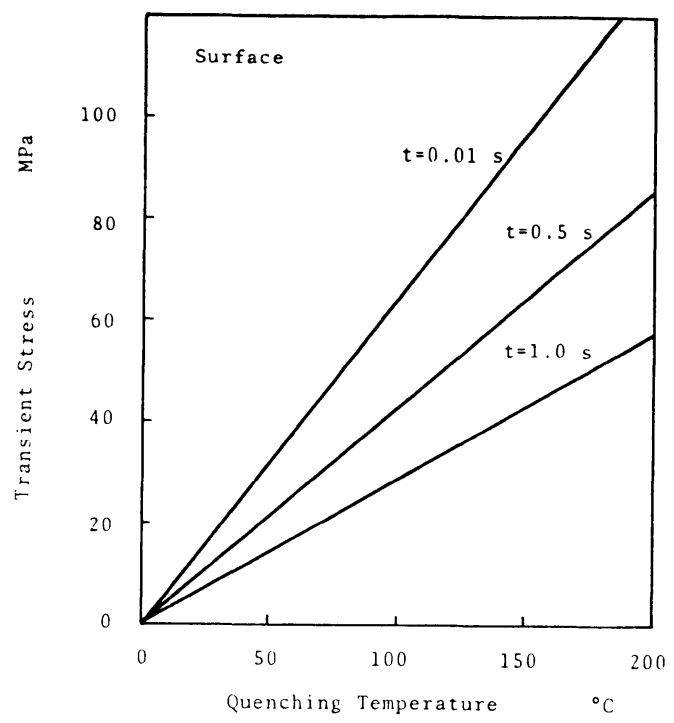

Fig. 6 Relation between transient stress and heat-soaked temperature for porcelain beam with $2.5 \mathrm{~mm}$ thickness. $\alpha_{p}=14 \times 10^{-6} /{ }^{\circ} \mathrm{C}$; and $E_{p}=70 \mathrm{GP}$.

the porcelain has a low coefficient, the contraction of the porcelain is small and the internal stress is then low. The jorcelain which has a low coefficient of thermal expansion has high thermal shock resistance. Figure 8 shows the experimental results of thermal shock tests for the specimen A. The surface cracks in (a), (b), (c) and (d) show the results of quenching from $125,150,200$ and $250^{\circ} \mathrm{C}$, respectively. The maximum tensile transient stresses, as estimated from the simulation results, reached 79, 94, 107 and $157 \mathrm{MPa}$. The patterns of these cracks show clearly the magnitudes of these transient stresses. The cracks were not initiated below $100^{\circ} \mathrm{C}$ quenching temperature. Figure 9 shows the results for specimen $\mathrm{B}$. The transient stresses calculated are $69,82,110$ and $137 \mathrm{MPa}$, respectively. Ten specimens, which have the same dimensions as specimen $\mathrm{B}$, were tested. When quenched from $120^{\circ} \mathrm{C}$, none of these specimens show cracks. When quenched from $130^{\circ} \mathrm{C}$, the ten specimens had surface cracks.

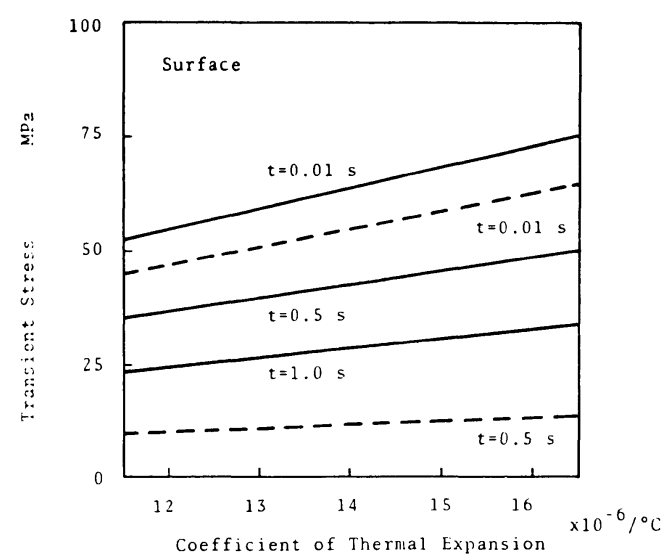

Fig. 7 Relation between transient stress and linear coefficient of thermal expansion for the porcelain with $2.5 \mathrm{~mm}$ thickness quenched from heat-soaked temperature $100^{\circ} \mathrm{C}$ to $0^{\circ} \mathrm{C}$ ice water. $E_{p}=70 \mathrm{GPa}_{\mathrm{a}}$. 

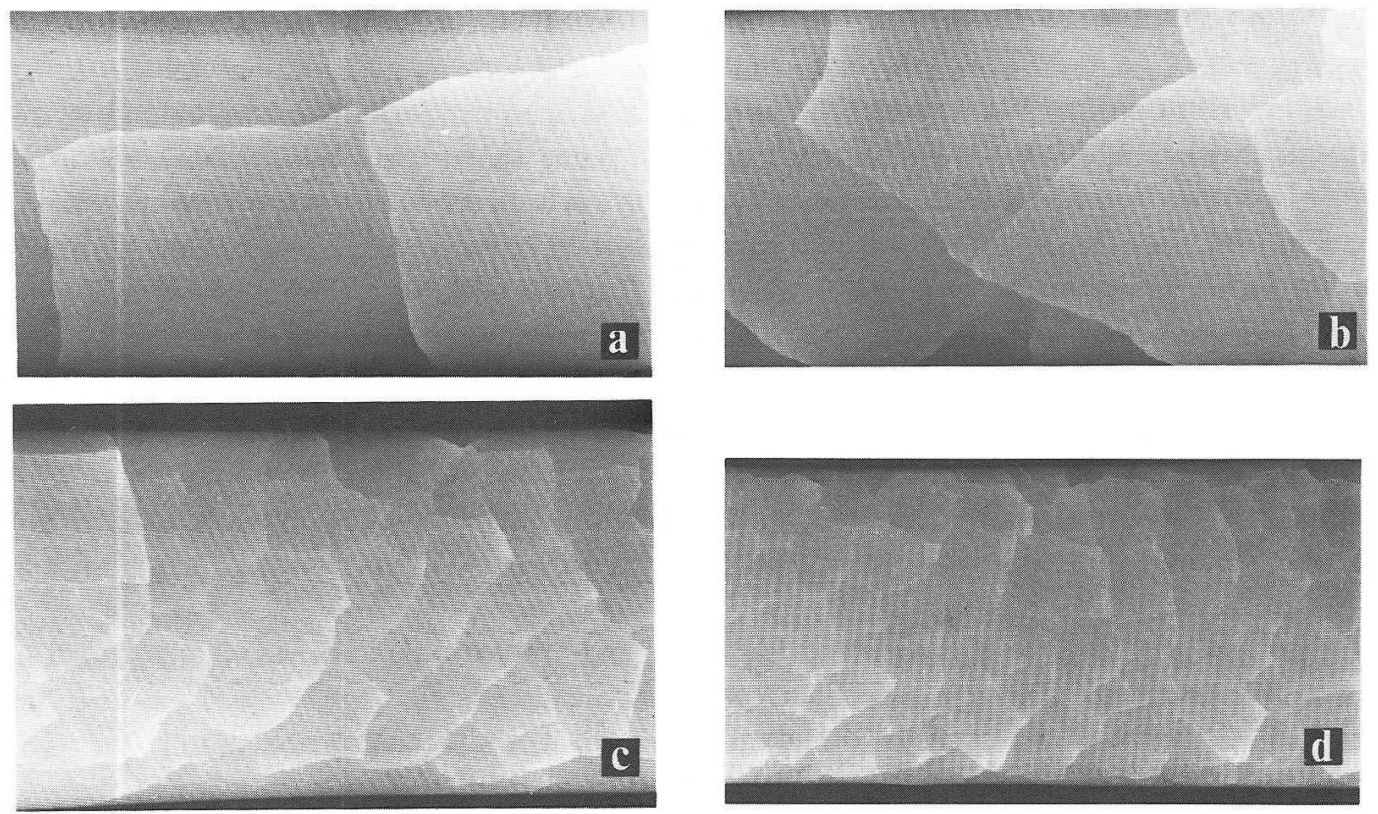

Fig. 8 Cracks development in the quenched porcelains with $2.5 \mathrm{~mm}$ thickness. (a) quenched into $0^{\circ} \mathrm{C}$ ice water from heat soaked temperature of $125^{\circ} \mathrm{C}$; (b) from $150^{\circ} \mathrm{C}$; (c) from $200^{\circ} \mathrm{C}$; and (d) from $250^{\circ} \mathrm{C}$.
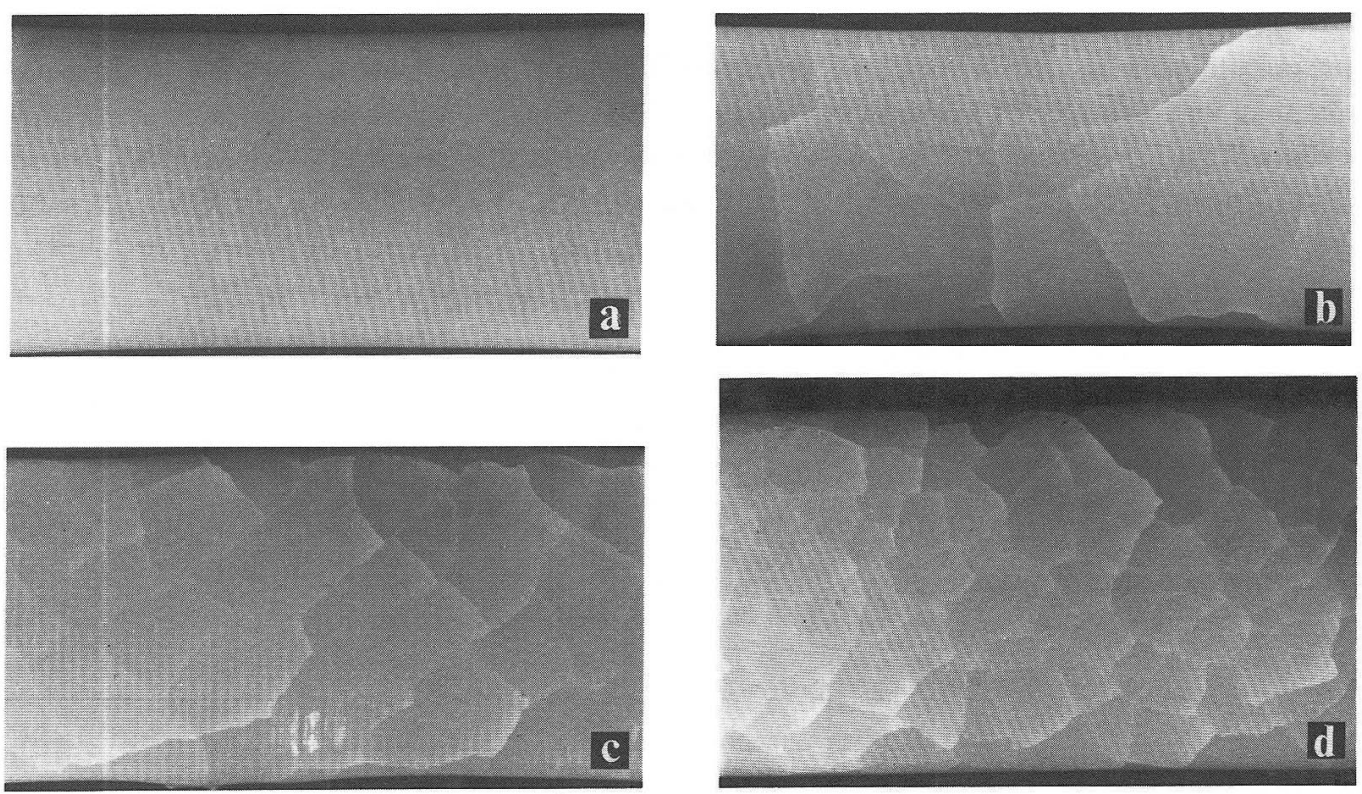

Fig. 9 Cracks development in the quenched porcelains with $1.25 \mathrm{~mm}$ thickness. (a) quenched into $0^{\circ} \mathrm{C}$ ice water from heat soaked temperature of $125^{\circ} \mathrm{C}$; (b) from $150^{\circ} \mathrm{C}$; (c) from $200^{\circ} \mathrm{C}$; and (d) from $250^{\circ} \mathrm{C}$. 
The tensile strength of this porcelain was then estimated about $70 \mathrm{MPa}$. It is concluded that the thermal shock test is an easy and reliable test for tensile stength of porcelain.

Porcelain-Opaque-The thermal expansion/shrinkage of the opaque porcelain above the glass transition temperature, is different from that of body porcelain. Below that temperatur$\mathrm{e}$, thermal deformation of these two porcelains is very close. The elastic modulus of the opaque porcelain assumed to be close to that of the body porcelain. Six specimens with 1.25 $\mathrm{mm}$ thickness were made to combine body and opaque porcelain. The thickness of opaque porcelain was about $0.25 \mathrm{~mm}$. For these specimens, surface cracks were observed in 2, 3 and 1 specimens with quenching temperatures from 120,130 and $140^{\circ} \mathrm{C}$, respectively. The maximum tensile stresses were calculated as 66,72 and $77 \mathrm{MPa}$ from the results of simulation. These strengths were nearly the same as those found for the body porcelain.

Porcelain-Opaque-Alloy-A deeper understanding of the data for compatibility in PFM can be acquired by comparing the difference of stress distributions between porcelain and PFM during the quenching test.

Several situations are considered: (A) Alloy and porcelain have the same coefficient of thermal expansion. Transient stress in the specimen is determined by the elastic moduli, the coefficients of thermal expansion, thickness and shape of the combined materials. The assumptions made on this calculation are that the beam has no internal stress before thermal shock test and the alloy and porcelains have the same value of the coefficients of thermal expansion; $14 \times 10^{-6{ }^{\circ}} \mathrm{C}^{-1}$ (Whitlock et al. ${ }^{13)}$, Fairhurst et $a l .{ }^{14)}$ ). The elastic moduli of alloy and porcelain are chosen 80 and $70 \mathrm{GPa}$, respectively $\left(\mathrm{Nielsen}^{15)}\right.$, Kase et $\left.a{ }^{16}{ }^{16}\right)$. Thickness of the porcelain and the alloy are 2.5 and $0.5 \mathrm{~mm}$.

Figures 10 and 11 show the transient stresses at the surface and at the interface of the specimen A and B. Line A represents the transient stress at the surface of the porcelain-only specimen and lines $B$ and $C$ show the stresses at the surface and at the interface of the PFM systems. The specimen with the alloy has higher surface tensile stresses than the specimen without the alloy, but the interfacial stress is not so high. In this case, the surface cracks may

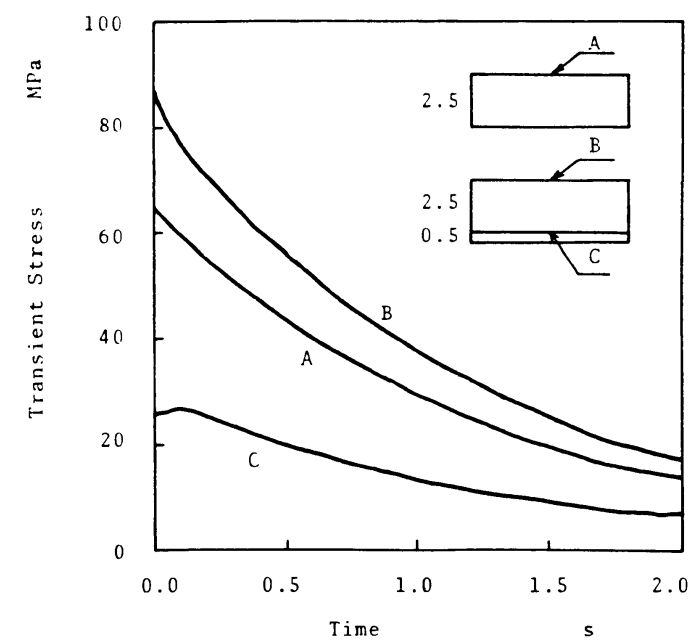

Fig. 10 Transient stress profile for porcelain $\mathrm{A}$ and porcelain $\mathrm{A}$ with the alloy heat-soaked at $100^{\circ} \mathrm{C}$ and quenched in $0^{\circ} \mathrm{C}$ ice water. $h_{p}=2.5 \mathrm{~mm} ; h_{m}=$ $0.5 \mathrm{~mm}$; and $\alpha_{p}=\alpha_{m}=14 \times 16^{-6} /{ }^{\circ} \mathrm{C}$. 


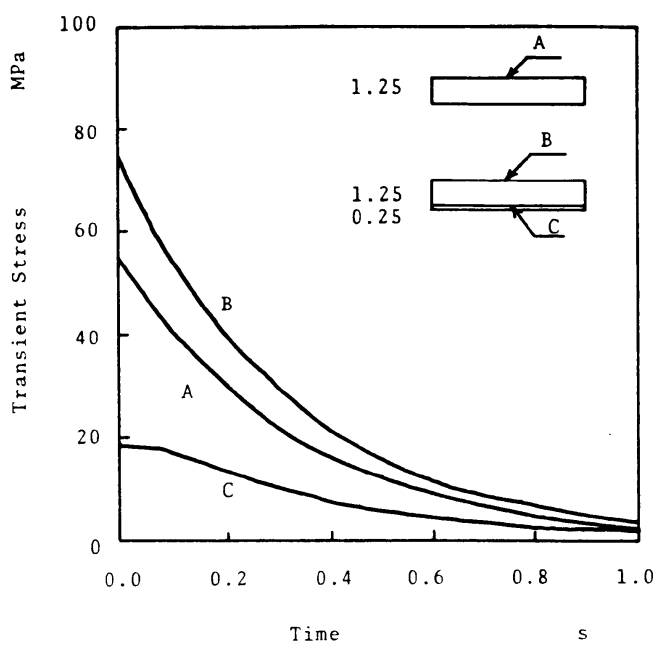

Fig. 11 Transient stress profile for porcelain B and porcelain B with the alloy heat-soaked at $100^{\circ} \mathrm{C}$ and quenched in $0^{\circ} \mathrm{C}$ ice water. $h_{p}=1.25 \mathrm{~mm} ; h_{m}=$ $0.25 \mathrm{~mm}$; and $\alpha_{p}=\alpha_{m}=14 \times 10^{-6} /{ }^{\circ} \mathrm{C}$.

then be more easily initiated than for the porcelain-only specimen. The specimen with greater thickness has higher transient stress at the surface.

Figure 12 shows the stress distribution at $0.01,0.1$ and $0.5 \mathrm{~s}$ after quenching for the specimen A. Under steady state conditions the internal stress is zero because temperature in the specimen is kept equal and the materials have the same coefficient of thermal expansion. For the quenching case, tensile stress is developed near both sides of the surface and

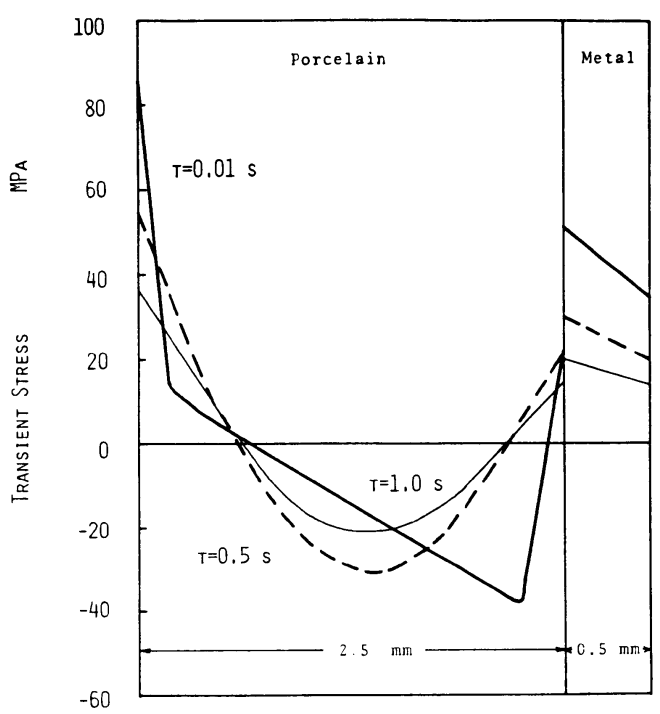

Fig. 12 Total transient stress profiles $0.01,0.5$ and $1.0 \mathrm{~s}$ after quenching BodyOpaque-Alloy composite beam in $0^{\circ} \mathrm{C}$ ice water from heat soaked temperature of $100^{\circ} \mathrm{C} . E_{p}=70 \mathrm{GP}_{\mathrm{a}} ; E_{m}=80 \mathrm{GP}_{\mathrm{a}} ; h_{p}=2.5 \mathrm{~mm} ; h_{m}=0.5 \mathrm{~mm}$; and $\alpha_{p}=\alpha_{m}=14 \times 10^{-6} /{ }^{\circ} \mathrm{C}$. 
compressive stress occurs at the center of the specimen. At the porcelain-alloy interface, tensile stress is not as high as the stress at the surface and not changed extremely with time.

(B) Alloy and porcelain have different coefficients of thermal expansion. In this case, the composite beam has residual stress under steady state conditions. The time dependent internal stress during quenching is represented as the sum of this residual stress and the transient stress. The residual stress is naturally changed due to temperature changes. The internal stress of the porcelain is closely related to the glass transition temperature. These physical properties are essential for calculating the residual stress in the porcelain. The coefficient of thermal expansion and elastic modulus are dependent on temperature. It is desirable to compute the residual stress in PFM under steady state conditions with these factors. However, in this simulation the elastic moduli and the coefficients of thermal

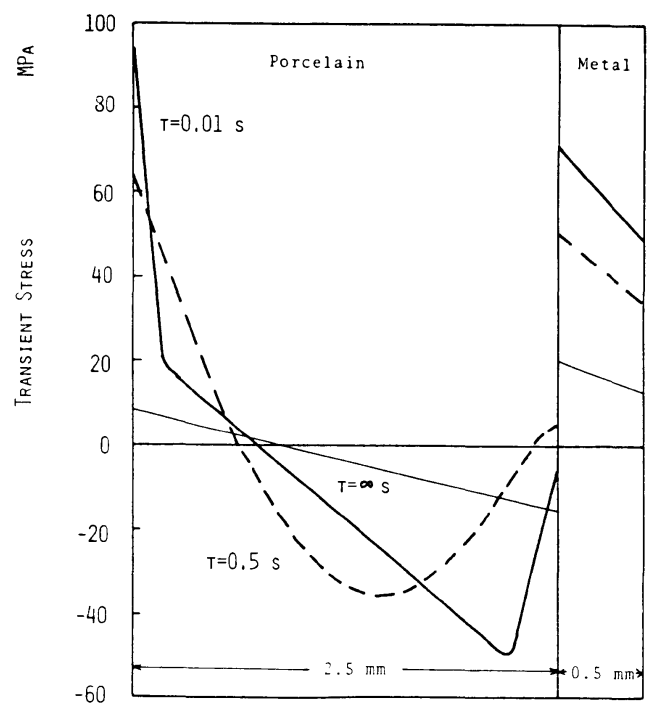

Fig. 13 Total ransient stress profiles $0.01,0.5$ and $1.0 \mathrm{~s}$ after quenching BodyOpaque-Alloy composite beam in $0^{\circ} \mathrm{C}$ ice water from heat-soaked temperature of $100^{\circ} \mathrm{C} . E=70 \mathrm{GP}_{\mathrm{a}} ; E_{m}=80 \mathrm{GP}_{\mathrm{a}} ; h_{p}=2.5 \mathrm{~mm} ; h_{m}=0.5 \mathrm{~mm}$; $\alpha_{p}=14 \times 10^{-6} /{ }^{\circ} \mathrm{C}$; and $\alpha_{m}=15 \times 10^{-6} /{ }^{\circ} \mathrm{C}$.

expansion are presumed to be constant values below the porcelain glass transition temperature. The transition temperature is taken at $570^{\circ} \mathrm{C}$.

Figure 13 show the results for the case of $\alpha_{m}>\alpha_{p}$. A solid line shows the stress at 0.01 $\mathrm{sec}$ after quenching, a broken line is for $0.5 \mathrm{~s}$, and a fine line is the normal stress distribution across the beam under the infinite cooling time. The tensile stress at the interface is higher than for the case of $\alpha_{m}=\alpha_{p}$. The surface cracks will be then initiated with about a $10^{\circ} \mathrm{C}$ lower quenching temperature.

Figure 14 shows the case of $\alpha_{m}<\alpha_{p}$. In this case, surface tensile stress is low. The surface of the porcelain has the compressive stress under infinite cooling time. But, the porcelain-alloy interface has high tensile stress. In general, the fracture strength of the interface should be lower than the surface. The surface of porcelain is smooth and has not many defects. However, the interface has many small gas bubbles and defects with metal 


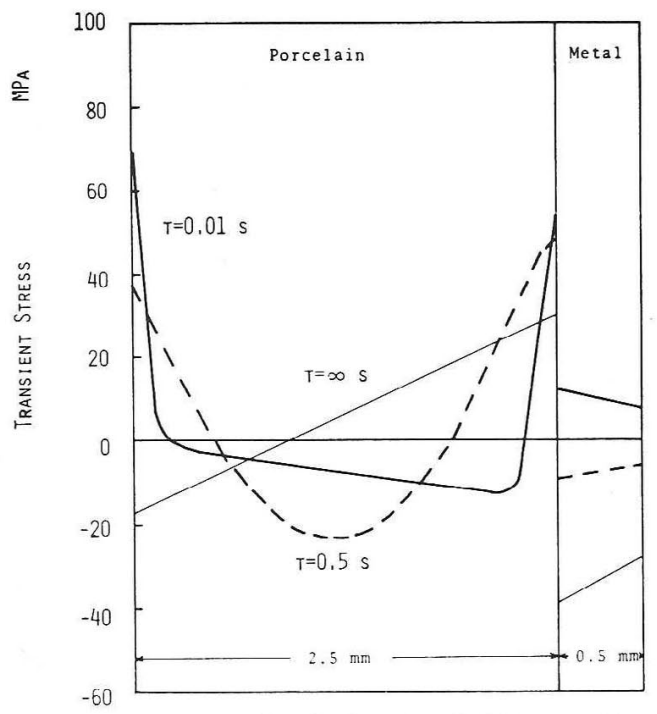

Fig. 14 Total transient stress profiles $0.01,0.5$ and $1.0 \mathrm{sec}$ after quenching BodyOpaque-Alloy composite beam in $0^{\circ} \mathrm{C}$ ice water from heat-soaked temperature of $100^{\circ} \mathrm{C} . \quad E=70 \mathrm{GPa} ; E_{m}=80 \mathrm{GPa}_{\mathrm{a}} ; h_{p}=2.5 \mathrm{~mm} ; h_{m}=0.5 \mathrm{~mm}$; $\alpha_{p}=14 \times 10^{-6} /{ }^{\circ} \mathrm{C}$; and $\alpha_{m}=12 \times 10^{-6} /{ }^{\circ} \mathrm{C}$.

oxides. For this reason, it is preferable to use the alloy with a lower thermal expansion than that of porcelain. The critical point of the difference $\alpha_{p}-\alpha_{m}$ is determined for the interfacial fracture. The results of simulation show the difference of $\Delta \alpha=2 \times 10^{-6^{\circ}} \mathrm{C}^{-1}$ is the limit to provide protection against the interfacial cracks.

Thermal shock test was done for three kinds of fused alloys. For the beam with Alloy A, the surface cracks were observed with a quenching temperature $90^{\circ} \mathrm{C}$ of all seven specimens. The surface cracks were observed for Alloy B, that is, one sample had from $80^{\circ} \mathrm{C}$ and other two samples had from $100^{\circ} \mathrm{C}$. All of the specimens with Alloy C had interfacial cracks for quenching from $130^{\circ} \mathrm{C}$. Figure 15 shows the interfacial cracks for the beam with Alloy C. Thermal expansion coefficients of these alloys are $13.8,15.4$ and $12.7 \times 10^{-6^{\circ}} \mathrm{C}^{-1}$, respectively. These results are then in general agreement with the simulation results. For

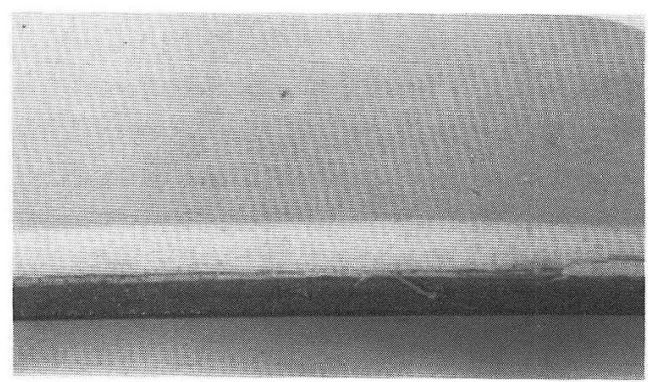

Fig. 15 Interfacial crack development in the Porcelain-Opaque-Alloy $\mathrm{C}$ beam quenched in $0^{\circ} \mathrm{C}$ ice water from heat soaked temperature of $130^{\circ} \mathrm{C}$. 
more detailed discussion, it may be required that the residual stress before thermal shock tests are determined from temperature depended physico-mechanical properties.

\section{CONCLUSION}

Computer calculations were used to simulate the effects of thermal shock on the stresses developed in PFM systems. A three-dimensional-finite element model was employed to first calculate time-dependent temperature distribution. These were then used in a twodimensional analysis of stresses in a beam consisting of 50 elements. Transient stresses were calculated for porcelain, porcelain with an opaque layer, and porcelain-opaque-alloy system. Experimental tests were also conducted for correlation with the theoretical calculations. The following conclusions were reached:

1. This study shows that thermal shock test is easy to perform and is a reliable method to measure the strength of porcelain. The influence of the coefficient of thermal expansion, thickness of the beam, and quenching temperature on transient stress were determined from the simulation.

2. The experimental test of porcelain with an opaque layer shows that the transient stress in the beam which was combined with two porcelains which have close physicomechanical properties is not changed.

3. The coefficient of thermal expansion of alloy has a major influence on thermal shock resistance of porcelain-opaque-alloy beam. When $\alpha_{m}>\alpha_{p}$, higher stress occurs on the surface of porcelain, and the interface stress is lower than for $\alpha_{m}=\alpha_{p}$. When $\alpha_{m}<\alpha_{p}$, the surface stress is lower and interface stress is higher than $\alpha_{m}=\alpha_{p}$. When $\alpha_{p}-\alpha_{m}>2 \times$ $10^{-6^{\circ}} \mathrm{C}^{-1}$, cracks are more easily initiated in the porcelain surface. Theory and experiment are in general agreement.

For a more detailed consideration of this problem, it is highly desirable to use temperature dependent physico-mechanical properties.

\section{ACKNOWLEDGEMENTS}

The authors wish to thank Dr. John A. Tesk, Group Leader, Dental and Medical Materials, National Bureau of Standards, for valuable suggestions in preparation of this manuscript. This research was supported by grants from Japanese Ministry of Education.

\section{REFERENCES}

1) Anusavice, K. J., Dehoff, P. H., and Fairhurst, C. W.: Comparative Evaluation of Ceramic-Metal Bond Test using Finite Element Stress Analysis, J Dent Res 59: 608-613, 1980.

2) Asaoka, K. and Kuwayama, N.: Studies on Mechanical Properties of Metal-Ceramic RestorationEstimate of Bond Strength by Pull-out Test, J Japan Soc Dent Appar Mat 21 : 103-108, 1980.

3) Dehoff, P. H., Anusavice, K. J., and Hathcock, P. W.: An Evaluation of the Four-point Flexural Test for Metal-Ceramic Bond Strength, J Dent Res 61 : 1066-1069, 1982.

4) Asaoka, K. and Kuwayama, N.: Studies on Mechanical Properties of Metal-Ceramic RestorationResidual Stress and Deformation during Cooling Down, J J Dent Mat 1: 10-16, 1982.

5) Asaoka, K. and Kuwayama, N.: Evaluation of Thermal Residual Stress after Firing for Porcelain/ 
Alloy Veneer, Dent Mat J 3: 139-147, 1984.

6) Tesk J. A., Whitlock, R. P., Widera, G. E. O., Holmes, A. D., and Parry, E. E. : Consideration of Some Factors Influencing Compatibility of Dental Porcelains and Alloys. Part II : Porcelain/Alloy Stress, Proceedings of 4th Int. Precious Metals Conf., Toronto, Canada : Pergamon Press, 1981.

7) Tesk, J. A., Hinman, R. W., Widera, G. E. O., Holmes, A. D., and Cassel, J. M. : Effects of Porcelain/ Alloy Interfacial Diffusion Zones on Thermo-mechanical Strain, J Dent Res 62: 585-589, 1983.

8) Dehoff, P.H. and Anusavice, K. J.: Analysis of Alloy-Porcelain Compatibility Using a Multicomponent Material Strip Equation, J Dent Res 64: 1337-1344, 1985.

9) Walton, T. R. and O'Brien, W. J. : Thermal Stress Failure of Porcelain Bonded to a Palladium-Silver Alloy, J Dent Res 64: 476-480, 1985.

10) Anusavice, K. J., Ringle, R. D., Morse, P. K., Fairhurst, C. W., and King, G. E. : A Thermal Shock Test for Porcelain-Metal Systems, J Dent Res 60 : 1686-1691, 1981.

11) Anusavice, K. J., Twiggs, S. W., Dehoff, P. H., and Fairhurst, C. W. : Correlation of Thermal Shock Resistance with Thermal Compatibility Data for Porcelain-Metal Systems, J Dent Res 61 : 419-422, 1982.

12) Anusavice, K. J., Dehoff, P. H., Twiggs, S. W., and Lockwood, P. C. : Thermal Shock resistance of Porcelain Discs, J Dent Res 62: 1082-1085, 1983.

13) Whitlock, R. P., Tesk, J. A., Widera, G. E. O., Holmes, A., and Parry, E. E. : Consideration of Some Factors Influencing Compatibility of Dental Porcelains and Alloys, Part I: Thermo-physical Properties; Proceedings of 4th Int. Precious Metals Conf., Toronto, Canada: Pergamon Press, 1981.

14) Fairhurst, C. W., Anusavice, K. J., Hashinger, D. T., Ringle, R. D., and Twiggs, S. W.: Thermal Expansion of Dental Alloys and Porcelains, J Biomed Mat Res 14: 435-446, 1980.

15) Nielson, J. P.: Gold in Dentistry, In ASM metals handbook Vol. 2, Properties and Selection : Nonferrous Alloys and Pure Metals, Cleveland: American Society for Metals, 1979, pp. 684-687.

16) Kasel H. R., Tesk, J. A., and Case, E. D. : Elastic Constants of Two Dental Porcelains, J Mat Sci 20 : 524-531, 1985. 


\title{
本号掲載論文の和文抄録
}

\author{
熱衝撃試験による金属焼付陶材中の残留応力の評価 \\ 浅岡憲三，桑山則彦 \\ 徳島大学茵学部茵科理工学講座
}

金属焼付陶材の熱衝撃試験をコンピュータシミュレー ションした。すなわち, 初めに 3 次元熱伝導有限要素法 を利用して陶材中の温度分布を求め, その結果をもとに 梁の理論から試験片内の内部応力を計算した。シミュ レーションは陶材, 陶材一オペーク陶材, 陶材ーオペー ク陶材一合金の 3 種の試料について試みた。そして, 板 厚, 熱膨張係数, 焼き入れ温度とTransient stress との 関係について調べ, 以下の結論を得た。 $\alpha_{\mathrm{m}}($ 金属 $)>\alpha_{\mathrm{p}}$ (陶材) の場合, $\alpha_{\mathrm{m}}=\alpha_{\mathrm{p}}$ の場合よりも 陶材表面の応力は高く, 界面での応力は低くなる。また, $\alpha_{\mathrm{m}}<\alpha_{\mathrm{p}}$ の場合には陶材表面の応力は低くなるが, 界面で の応力は高くなる。金属焼付陶材の界面破壊を防ぐには $\alpha_{\mathrm{p}}-\alpha_{\mathrm{m}}$ が $2 \times 10^{-6 \circ} \mathrm{C}^{-1}$ より小さくなくてはならない。

熱膨張係数の異なる 3 種の合金に同じ陶材を焼き付 け，熱衝撃試験を試みた結果はシミュレーションの結果 と良く一致した。

接着性レジンによるアマルガムの窩洞への結合に関する研究

$$
\begin{gathered}
\text { バルガ・ユディト*, 松村英雄**, 増原英一** } \\
\text { *東京医科歯科大学蔝学部第二歯科補経学教室 } \\
\text { **東京医科歯科大学医用器材研究所有機材料部門 }
\end{gathered}
$$

アマルガム充填の際の辺縁封鎖性の向上や破折防止の ための基礎的研究として, 接着性レジンを窩壁に塗布し てから、アマルガムを充填する術式について検討した。 接着材としては酸無水物系モノマー, 4-META を含む MMA-TBB系レジン，および，リン酸エステル系モ， マーを含むパナビア EX を使用した。これらのレジンを 窝壁に塗布してからアマルガムを充填し, 辺縁の漏洩防
止効果と接着強さを測定した。その結果, 接着性レジン を塗布してからアマルガムを充填すると辺縁封鎖に対し 有効であることが明らかになった。また，エナメル質を 酸処理した後，4-META-MMA-TBB 系レジンを塗布 し,アマルガムを充填した場合, 水中浸漬 1 カ月後でも 高い接着強さが得られた。

各種コンポジットレジンとエナメル質の擦り合わせ摩耗に関する研究 甲斐真貴子*，佐藤淳子*，佐藤尚毅*，新谷英章*, 藤岡道治**

*広島大学歯学部歯科保存学第一講座

各種コンポジットレジン (P-10, Clearfil Posterior, Clearfil F II, Palfique, Microjar, Microrest AP, Silar, P-30) と牛歯エナメル質を連続往復水平運動型摩耗試験 機を応用し，100,000 回の擦り合わせ摩耗試験を行うと ともに, 各種コンポジットレジンの諸性質 (フィラー含 有量, ヌープ硬度, 圧縮強度, 弾性率) を調へ, 擦り合
**広島大学歯学部歯科補緅学第一講座

わせ摩耗との関連性を検索した。

各種レジンの摩耗量は MFR 群に少なく, 他のレジン 間とに有意差が認められた $(\mathrm{p}<0.01)$ 。Microrest AP と Silarはほとんど摩耗されなかった。

レジンのフィラー含有量が多く, 硬度が高く, さらに 弾性率の高いレジン程, その摩耗量が多くなった。 